\title{
Studi Pendahuluan Untuk Meningkatkan Kemampuan Prososial Melalui Kemampuan Sosiokognitif Anak Usia 6 Tahun
}

\author{
Allessandra Theresia \\ Fakultas Psikologi, Universitas Pelita Harapan \\ Lippo Karawaci, Banten 15811, Indonesia \\ allessandra.theresia@uph.edu
}

Received 23 August 2019, Revised 3 September 2019, Accepted 17 September 2019

\begin{abstract}
This research is aimed to conduct preliminary study as a basic for improving 6-year-old sociocognitive skills. First, we do an assessment to get information about learning needs of sociocognitive skills by measuring about general intelligence, perception of others, role-taking, attribution of other, and moral reasoning abilities. The assessment is conducted by illustrated stories and questionnaires given to teachers as agents of socialization for children. After classifying children 6 years of age who exhibit prosocial behavior or not by asking the teachers, then each child will be given a picture about prosocial situations descriptively. The data obtained and analyzed descriptively to determine the learning needs of the ability of children aged 6 years sosiocognitive. The assessment indicates children with better sociocognitive skills will do more prosocial behavior that problem of sociocognitive skills is not found in the 6-year-old children who can perform prosocial behavior, but the problem is found from the children 6 years of age who do not exhibit prosocial behavior. Based on the learning needs, researchers are preparing an intervention program of activities such as role play and discussion about prosocial situations.

Keywords: Sociocognitive Skills, Prosocial behaviors, Intervention
\end{abstract}

\begin{abstract}
Abstrak - Penelitian ini bertujuan melakukan studi pendahuluan sebagai dasar intervensi meningkatkan kemampuan prososial anak melalui kemampuan sosiokognitif yang dimiliki anak usia 6 tahun. Untuk itu perlu dilakukan pemeriksaan kebutuhan belajar untuk meningkatkan kemampuan sosiokognitif sehingga dapat menyusun program intervensi yang sesuai. Pemeriksaan dilakukan melalui pengukuran dimensi general intelligence, perception of others, role taking, attribution of others, dan kemampuan moral reasoning dalam bentuk cerita bergambar dan angket yang diberikan kepada guru sebagai agen sosialisasi bagi anak usia 6 tahun. Kemudian masing-masing anak yang telah dikelompokkan melakukan perilaku prososial dan tidak melakukan perilaku prorosial akan diberikan kartu bergambar mengenai situasi-situasi prososial. Data yang diperoleh kemudian dianalisis secara deskriptif untuk mengetahui kebutuhan belajar dari kemampuan sosiokognitif anak usia 6 tahun. Hasil pemeriksaan menunjukkan bahwa tidak ditemukan permasalahan dalam kemampuan sosiokognitif anak usia 6 tahun yang menunjukkan perilaku prososial. Permsaalahan dalam kemampuan sosiokognitif ditemukan pada anak yang tidak menunjukkan perilaku prososial. Berdasarkan kebutuhan belajar yang diperoleh, peneliti menyusun program rancangan berupa kegiatan role play dan diskusi mengenai situasi-situasi prososial.

Kata Kunci: Kemampuan Sosiokognitif, Perilaku prososial, Intervens
\end{abstract}

\section{PENDAHULUAN}

Pada anak usia enam tahun, salah satu ciri perkembangannya adalah ditandai dengan perhatian pada pertemanan, dan penjelajahan mengenai kemampuan social (Gestwicki, 2007). Usia ini merupakan usia yang penting karena di masa ini anak mulai senang bermain secara berkelompok dan mulai memahami peraturan-peraturan yang ada di lingkungan (Byron, 2009). Pada usia ini anak juga mengetahui dasar dari hal yang benar dan salah, misalnya tidak boleh menyakiti teman dan harus menolong orang yang sedang kesusahan serta belajar memahami peran-peran yang ada di lingkungan.
Dalam hal ini anak membutuhkan perilaku sosial yang positif utnuk bisa bergaul dan bersosialisasi di masyarakat. Menurut Mullis, Smith, dan Vollmers (1983) salah satu bentuk perilaku positif yang membedakan manusia dengan spesies lainnya adalah kemampuan untuk menolong, berbagi, memperhatikan dan menyediakan kenyamanan bagi orang lain dan bentuk perilaku ini umum disebut sebagai perilaku prososial. Perilaku prososial ini mendorong perkembangan pikiran, perasaan, dan perilaku memperhatikan orang lain sehingga menjadi faktor penting dalam interaksi anak dengan lingkungan. 
Pertimbangan pentingnya perilaku prososial dalam perkembangan anak, peneliti melakukan observasi di kelas mengenai interaksi sosial anak usia 6 tahun dalam setting sekolah. Pengamatan di lakukan di salah satu sekolah di Palembang dan sekolah inklusi di Pangkal Pinang dalam situasi belajar dan bermain. Hasil observasi menunjukkan bahwa beberapa anak melakukan perilaku non prososial seperti mentertawakan ketika ada teman jatuh, meneriakkan teman yang tidak bisa menjawab pertanyaan atau memukul ketika ada perilaku teman yang tidak disukai. Peneliti juga melakukan wawancara dengan guru-guru di kelas di kedua sekolah tersebut dan ditemukan data bahwa guru-guru di kelas sebenarnya sudah mengkondisikan anak-anak untuk bisa berperilaku prososial seperti meminta anak-anak untuk bisa membantu teman-temannya yang tidak memiliki alat tulis dengan meminjamkan alat tulis yang mereka punya, membantu mengajari teman-teman yang masih belum bisa dalam pelajaran, dan mengingatkan anak untuk mengucapkan terima kasih setelah menerima bantuan. Namun dalam kesehariannya, masih ada anak yang memang belum menunjukkan perilaku prososial.

Secara lebih spesifik, perkembangan perilaku prososial dapat dipengaruhi oleh faktor-faktor yang meliputi, biologis, budaya, pengalaman sosialisasi, proses kognitif, respon emosional, kepribadian dan terakhir variable personal yang meliputi kemampuan sosialisasi, jenis kelamin, kondisi situasi dan lingkungan (Eisenberg, 1989). Eisenberg dan Mussen (1989) juga menjelaskan ketika anak akan memutuskan bahwa ia akan berperilaku prososial atau tidak, anak akan melewati proses seperti menginterpretasi situasi, memberikan atensi terhadap kebutuhan orang lain, mengidentifikasi perilaku prososial dan pengenalan kemampuan untuk bisa terlibat dalam perilaku prososial, kemudian menentukan hirarki tujuan personal dalam situasi tersebut, kemudian ia memutuskan bahwa ia berniat untuk menolong atau tidak, dan terakhir anak akan mengevaluasi perilaku yang telah ia lakukan. Eisenberg dan Mussen (1989) juga mengatakan sebelum anak menggunakan kemampuan kognitifnya dalam menginterpretasi situasi sosial, anak perlu untuk memahami reaksi emosi yang dirasakan orang lain kemudian menentukan bentuk perilaku prososial yang tepat untuk mengurangi kesedihan orang lain. Kesemua proses tersebut merupakan komponen dalam kemampuan sosiokognitif.

Lebih lanjut, Piaget (dalam Berk, 2003) mengatakan bahwa kematangan kemampuan sosiokognitif seorang anak akan mempengaruhi keputusan anak dalam berperilaku prososial. Fungsifungsi dalam dimensi kemampuan sosiokognitif penting untuk membantu anak bisa menginterpretasi dengan tepat kesedihan yang dialami orang lain melalui interpretasi terhadap ekspresi wajah.

Uraian diatas menunjukkan bahwa kemampuan sosiokognitif perlu dimiliki anak untuk mematangkan kemampuannya dalam berperilaku prososial. Oleh karena itu perlu dibuat suatu rancangan intervensi untuk membantu anak usia 6 tahun untuk meningkatkan kemampuan sosiokognitf agar bisa berperilaku prososial dengan tepat.

Beberapa hal yang akan menjadi pertanyaan dalam penelitian ini adalah gambaran kemampuan sosiokognitif yang ditunjukkan anak usia 6 tahun yang menunjukkan perilaku prososial dan yang tidak menunjukkan perilaku prososial, kebutuhan belajar yang diperlukan anak usia 6 tahun untuk bisa meningkatkan kemampuan sosiokognitif sehingga bisa berperilaku prososial, dan program intervensi yang sesuai bagi anak usia 6 tahun sehingga bisa meningkatkan kemampuan sosiokognitif. Berdasarkan pertanyaan tersebut, penelitian ini dibuat untuk melakukan pemeriksaan dalam rangka menemukan faktor-faktor yang dapat menyebabkan rendahnya kemampuan sosiokognitif anak usia 6 tahun sehingga pada akhirnya bisa meningkatkan perilaku prososial.

Pada penelitian ini, peneliti akan fokus padahahal berikut:

- Kondisi dimensi kemampuan sosiokognitif seperti apa yang ditunjukkan anak usia 6 tahun yang menunjukkan perilaku prososial dan tidak menunjukkan perilaku prososial?

- Kebutuhan belajar seperti apa yang diperlukan anak usia 6 tahun untuk bisa meningkatkan dimensi kemampuan sosiokognitif sehingga bisa berperilaku prososial?

- Program intervensi seperti apa yang sesuai bagi anak usia 6 tahun sehingga bisa meningkatkan kemampuan sosiokognitif?

Tujuan penelitian adalah membuat rancangan intervensi untuk meningkatkan level perkembangan sosiokognitif anak usia 6 tahun. Dengan meningkatkan kemampuan sosiokognitif diharapkan mampu meningkatkan kemampuan prososialnya.

\section{TINJAUAN LITERATUR}

Untuk melengkapi tujuan penelitian diatas maka digunakan tinjauan teori dengan menggunakan teori menurut Eisenberg dan Mussen (1989). Menurut Eisenberg dan Mussen, perilaku prososial merupakan perilaku sukarela yang bertujuan untuk menolong atau memberikan keuntungan kepada orang lain atau sekelompok orang. Perilaku prososial ini oleh Eisenberg dan Mussen didefinisikan berdasarkan konsekuensi niat yang dilakukan terhadap orang lain. Beberapa bentuk perilaku prososial menurut Eisenberg dan Mussen (1989), yaitu kemurahan hati, ekspresi simpati, berbagi kepunyaan, memberikan sumbangan dan aktivitas-aktivitas lain yang dilakukan untuk kesejahteraan komunitas dengan mengurangi ketidakadilan dan ketidaksamaan sosial.

Eisenberg (1982) menyatakan bahwa ada lima tahapan perkembangan pemikiran mengenai isu dalam perilaku prososial. Berdasarkan kelima tahapan tersebut, anak usia 6 tahun berada pada tahap 1 
(hedonistic, self-focused orientation) atau tahap 2 (need-oriented orientation). Pada tahap 1, anak lebih memperhatikan konsekuensi suatu tindakan terhadap diri sendiri daripada nilai-nilai dalam diri yang dimiliki. Di dalam alasan anak untuk membantu atau tidak membantu orang lain terdapat harapan untuk memperoleh keuntungan bagi diri sendiri dan timbal balik di masa yang akan dating, serta perhatian anak pada orang lain muncul karena seseorang memerlukan dan atau menyukai orang lain (karena ikatan afeksi). Sedangkan tahap 2, mengekspresikan perhatiannya pada kebutuhan fisik, material, dan psikologi orang lain, meskipun kebutuhan orang lain tersebut bertentangan dengan kebutuhan orang lainnya. Dalam penelitian yang dilakukan oleh Murphy (dalam Eisenberg, Fabes, dan Spinrad, 2004) ditemukan bahwa anak usia 2 - 6 tahun bereaksi terhadap orang lain dengan berbagai cara berkisar dari cara yang simpatis dan prososial hingga ke reaksi yang tidak simpatis dan egois, seperti tertawa, agresi atau mengabaikan.

Menurut Eisenberg dan Mussen (1989) mengatakan bahwa didalam melakukan interaksi sosial yang melibatkan perilaku prososial, beberapa tahapan perlu dilalui seorang anak. Pada tahap awal, anak harus mampu mempersepsi dan menginterpretasi situasi dan membuat kesimpulan mengenai perasaan orang lain. Anak juga perlu mengevaluasi kebutuhan dan keinginan mereka untuk memutuskan perilaku mana yang paling efektif dan bermanfaat bagi mereka, dan memutuskan perilaku mana yang efektif dan bermanfaat untuk mereka. Pada akhirnya, anak harus merumuskan dan melaksanakan rencana untuk perilaku prososial. Jadi kesimpulannya, perilaku prososial meliputi sejumlah proses kognitif yaitu persepsi, reasoning, problem solving, dan decision making.

Menurut Eisenberg dan Mussen (1989) proses kognitif saja kurang bisa menjelaskan mengenai kemampuan anak untuk mempersepsi emosi orang lain, dan kemampuan untuk menyelesaikan permasalahan sosial dan moral. Dalam beberapa penelitian yang dilakukan beberapa ahli ditemukan bahwa kemampuan sosiokognitf terutama untuk kemampuan perception of others need memiliki pengaruh yang significant di dalam memprediksi kemampuan prososial anak. Karena respon prososial meliputi orientasi kognitif dan perilaku terhadap orang lain maka kemampuan sosiokognitif memberikan pengaruh terhadap perkembangan dan performance anak di lingkungan sosial. Dalam kemampuan sosiokognitif, menurut Eisenberg dan Mussen (1989) terdapat 5 aspek dimensi, yaitu general intelligence, perception of others' need, role taking, attributional inferences (inferences about others' motives and behavior), dan moral reasoning atau moral judgement.

General Intelligence untuk anak usia 6 tahun menurut Eisenberg dan Mussen (1989) mencakup kemampuan anak dalam menggunakan simbol, pemahaman sebab akibat, kemampuan klasifikasi, dan kemampuan anak berempati. Kemampuan menggunakan simbol meliputi kemampuan anak dalam mengenal ekspresi wajah sederhana dan berpikir mengenai situasi-situasi prososial. Untuk kemampuan klasifikasi meliputi kemampuan untuk memahami perbedaan dan persamaan ekspresi wajah sederhana. Kemudian dalam kemampuan empati mencakup kemampuan anak membayangkan peristiwa-peristiwa yang menyebabkan seseorang menjadi sedih, senang, marah, dan takut.

Menurut Eisenberg dan Mussen (1989) kemampuan perception of others' needs adalah kemampuan untuk membedakan secara perceptual antara diri sendiri dan orang lain dan secara akurat mampu untuk memahami reaksi emosional orang lain. Dalam hal ini anak mampu untuk mengindetifikasi, dan bersimpati terhadap kesedihan orang lain.

Lebih lanjut untuk kemampuan role taking menurut Eisenberg dan Mussen (1989) di usia 6 tahun mencakup kemampuan dalam memahami emosi sederhana dihubungkan dengan kejadian tertentu, kemampuan menceritakan perasaan yang dirasakan oleh orang lain dan merespon secara tepat signal emosi dari orang lain, serta kemampuan menggunakan cara efektif untuk mengurangi kesedihan orang lain.

Kemampuan attribution about others meliputi motivasi yang menyebabkan seorang anak berperilaku prososial atau memutuskan tidak berperilaku prososial. Dalam hal ini anak perlu memahami sebab akibat suatu kejadian sehingga pada akhirnya mampu untuk memotivasi diri untuk memberikan pertolongan kepada orang lain. Terakhir, kemampuan moral reasoning mencakup nilai-nilai yang diberikan agen sosialisasi seperti orang tua dan guru mengenai situasi prososial. Anak bisa memahami ketika ia menolong orang lain ia akan membuat orang lain menjadi senang dan merasa bersalah ketika ia mengejek orang yang sedang kesusahan.

\section{METODE PENELITIAN}

Penelitian ini merupakan penelitian yang bersifat deskriptif dengan menggunakan Teknik observasi dan wawancara yang mendalam. Penelitian ini bertujuan untuk merancang suatu program intervensi untuk meningkatkan kemampuan sosiokognitif anak usia 6 tahun di Pangkal Pinang. Populasi penelitian ini adalah anak usia 6 tahun yang bersekolah di SD di Pangkal Pinang. Dari 40 anak dilakukan pemeriksaan untuk menentukan anak-anak yang melakukan perilaku prososial dan yang tidak melakukan prososial. Kemudian dipilih 20 orang yang mewakili anak-anak yang melakukan perilaku prososial maupun yang tidak untuk diassess dan ditemukan kebutuhan belajarnya sehingga bisa menyusun program yang tepat. 
Tabel 1. Gambaran Dimensi Variabel Sosiokognitif untuk anak usia 6 tahun

\begin{tabular}{|c|c|}
\hline \multicolumn{2}{|c|}{ Pencapaian } \\
\hline \multicolumn{2}{|c|}{ General intelligence } \\
\hline - Menggunakan simbol & $\begin{array}{l}\text { - Anak mengenal ekspresi } \\
\text { wajah sederhana, yaitu } \\
\text { senang, sedih, marah, } \\
\text { dan takut. }\end{array}$ \\
\hline $\begin{array}{l}\text { - Pemahaman sebab- } \\
\text { akibat }\end{array}$ & $\begin{array}{l}\text { - Anak menyadari sebab } \\
\text { dan akibat dari ekspresi } \\
\text { wajah yang sederhana }\end{array}$ \\
\hline $\begin{array}{l}\text { - Kemampuan } \\
\text { klasifikasi }\end{array}$ & $\begin{array}{lr}\text { - Anak } & \text { memahami } \\
\text { perbedaan } & \text { dan } \\
\text { persamaan } & \text { ekspresi } \\
\text { wajah sederhana }\end{array}$ \\
\hline - Empati & $\begin{array}{l}\text { - Anak mampu } \\
\text { membayangkan seperti } \\
\text { apa ketika seseorang } \\
\text { sedih, senang, marah, } \\
\text { dan takut. }\end{array}$ \\
\hline \multicolumn{2}{|c|}{ Perception of others' needs } \\
\hline $\begin{array}{l}\text { - Kemampuan } \\
\text { mengklasifikasikan } \\
\text { orang lain secara } \\
\text { perceptual } \\
\text { - Kemampuan } \\
\text { memahami aturan }\end{array}$ & $\begin{array}{l}\text { - Kemampuan } \\
\text { menginterpretasikan } \\
\text { perbedaan ekspresi } \\
\text { wajah sederhana. } \\
\text { - Kemampuan untuk } \\
\text { memahami aturan yang } \\
\text { berlaku di lingkungan. }\end{array}$ \\
\hline \multicolumn{2}{|c|}{ Role taking } \\
\hline $\begin{array}{l}\text { - Kemampuan } \\
\text { memahami emosi } \\
\text { sederhana berhubungan }\end{array}$ & $\begin{array}{l}\text { - Kemampuan untuk } \\
\text { memahami kejadian- } \\
\text { kejadian yang melibatkan }\end{array}$ \\
\hline $\begin{array}{ll}\text { dengan } & \text { kejadian } \\
\text { tertentu } & \end{array}$ & $\begin{array}{l}\text { emosi sederhana dari } \\
\text { sudut pandang orang lain. }\end{array}$ \\
\hline $\begin{array}{l}\text { - Kemampuan untuk } \\
\text { menceritakan perasaan } \\
\text { yang dirasakan oleh } \\
\text { orang lain dan } \\
\text { merespon secara tepat } \\
\text { signal emosi dari orang } \\
\text { lain. }\end{array}$ & $\begin{array}{lr}\text { - Anak } & \text { mampu } \\
\text { menguraikan dan } & \text { menceritakan perasaan } \\
\text { yang dirasakan orang lain } \\
\text { dan memberikan respon } \\
\text { yang sesuai. }\end{array}$ \\
\hline $\begin{array}{l}\text { - Mampu menggunakan } \\
\text { cara yang efektif untuk } \\
\text { berperilaku prososial }\end{array}$ & 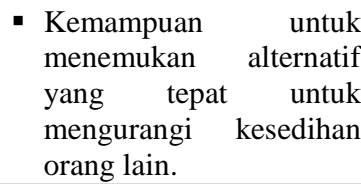 \\
\hline \multicolumn{2}{|c|}{ Attribution about others } \\
\hline $\begin{array}{l}\text { - Kemampuan } \\
\text { memotivasi diri untuk } \\
\text { meningkatkan perilaku } \\
\text { prososial }\end{array}$ & $\begin{array}{l}\text { - Kemampuan untuk } \\
\text { memahami sebab akibat } \\
\text { kejadian sehingga bisa } \\
\text { memotivasi diri untuk } \\
\text { memberikan pertolongan } \\
\text { pada orang lain. }\end{array}$ \\
\hline \multicolumn{2}{|c|}{ Moral reasoning } \\
\hline $\begin{array}{lr}\text { - } & \text { Kemampuan } \\
\text { memahami } & \text { nilai-nilai } \\
\text { moral } & \text { dalam } \\
\text { lingkungan } & \end{array}$ & $\begin{array}{l}\text { - Kemampuan memahami } \\
\text { nilai-nilai yang diberikan } \\
\text { oleh agen sosialisasi } \\
\text { terdekat seperti senang } \\
\text { ketika menolong dan } \\
\text { merasa bersalah ketika } \\
\text { mengejek. }\end{array}$ \\
\hline
\end{tabular}

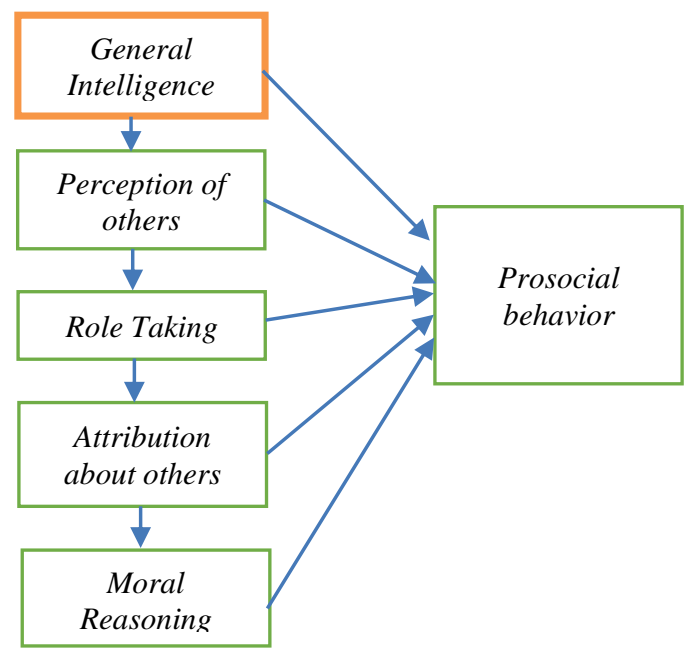

Gambar 1. Gambaran Proses Penelitian

\section{HASIL PENELITIAN DAN DISKUSI}

Berdasarkan hasil penelitian yang dilakukan dengan mengambil sampel anak-anak usia 6 tahun yang bersekolah di SD di Pangkal Pinang sebanyak 20 orang dari 40 siswa, maka diperoleh data yang cukup berbeda untuk anak berperilaku prososial dan tidak berperilaku prososial. Untuk anak yang berperilaku prososial ditemukan memiliki kemampuan yang tinggi dalam kemampuan general intelligence, menggunakan simbol, pemahaman kategorisasi, pemahaman sebab akibat, empati, perception of others' needs, mengklasifikasikan orang lain, mengkategorisasikan aturan, role taking, memahami emosi sederhana, mengungkapkan perasaan, menggunakan cara-cara efektif untuk mengurangi kesedihan orang lain, attribution of others, dan kemampuan moral reasoning.

Berdasarkan hasil pemeriksaan, ditemukan bahwa rata-rata dari sampel yang tidak menunjukkan perilaku prososial akan menunjukkan kemampuan general intelligence yang rendah. Anak usia 6 tahun yang memiliki kemampuan general intelligence yang rendah mampu untuk mengenali simbol berupa ekspresi sederhana, yaitu ekspresi marah, senang, sedih dan takut. Namun, mereka kesulitan untuk memahami perbedaan dan persamaan yang ada pada ekspresi-ekspresi tersebut hingga membuat kemampuan kategorisasi pun menjadi rendah.

Dari Tabel 1, anak usia 6 tahun ini juga mengalami kesulitan untuk melihat sebab akibat dari terjadinya ekspresi dari sudut pandang dirinya sendiri sehingga pada akhirnya kesulitan untuk menceritakan kejadiankejadian yang menyebabkan ia merasa sedih, senang, takut dan marah. Hal ini juga akhirnya mempengaruhi kemampuan anak dalam melihat kejadian-kejadian yang membuat membuat orang lain menjadi sedih, senang, takut, dan marah sehingga kemampuan empati juga menjadi rendah.

Sedangkan untuk anak-anak yang ditemukan tidak melakukan perilaku prososial memiliki kemampuan yang tinggi dalam kemampuan general intelligence dan kemampuan menggunakan simbol dan 
kemampuan yang rendah hampir di semua dimensi kemampuan sosiokognif seperti tertera di Tabel 2.

Tabel 2. Hasil Pengukuran

\begin{tabular}{|c|c|c|c|c|}
\hline Dimensi & $\begin{array}{l}\text { Anak } \\
\text { Berperi- } \\
\text { laku } \\
\text { proso- } \\
\text { sial }\end{array}$ & $\%$ & $\begin{array}{l}\text { Anak tidak } \\
\text { berperi- } \\
\text { laku } \\
\text { Prososial }\end{array}$ & $\%$ \\
\hline General & Tinggi & 100 & Tinggi & 44,4 \\
\hline Inteligence & & & Rendah & 55,6 \\
\hline $\begin{array}{l}\text { Menggunakan } \\
\text { simbol }\end{array}$ & Tinggi & 100 & Tinggi & 100 \\
\hline Pemahaman & Tinggi & 100 & Tinggi & 44,4 \\
\hline Kategorisasi & & & Rendah & 55,6 \\
\hline Pemahaman & Tinggi & 100 & Tinggi & 44.4 \\
\hline Sebab Akibat & & & Rendah & 55,6 \\
\hline Empati & Tinggi & 100 & Rendah & 100 \\
\hline $\begin{array}{l}\text { Perception of } \\
\text { other's needs }\end{array}$ & Tinggi & 100 & Tinggi & $\begin{array}{l}33.3 \\
44,4\end{array}$ \\
\hline $\begin{array}{l}\text { Mengklasifi- } \\
\text { kasikan orang } \\
\text { lain }\end{array}$ & Tinggi & 100 & $\begin{array}{l}\text { Rendah } \\
\text { Tinggi } \\
\text { Rendah }\end{array}$ & $\begin{array}{l}22,3 \\
44,4 \\
55,6\end{array}$ \\
\hline $\begin{array}{l}\text { Mengkatego- } \\
\text { risasikan }\end{array}$ & Tinggi & 100 & $\begin{array}{l}\text { Tinggi } \\
\text { Sedang } \\
\text { Rendah }\end{array}$ & $\begin{array}{l}44,5 \\
22,2 \\
33,3\end{array}$ \\
\hline Role Taking & Tinggi & 100 & $\begin{array}{l}\text { Tinggi } \\
\text { Rendah }\end{array}$ & $\begin{array}{l}44,4 \\
55,6\end{array}$ \\
\hline $\begin{array}{l}\text { Memahami } \\
\text { emosi } \\
\text { sederhana }\end{array}$ & Tinggi & 100 & $\begin{array}{l}\text { Tinggi } \\
\text { Rendah }\end{array}$ & $\begin{array}{l}55,6 \\
44,4\end{array}$ \\
\hline $\begin{array}{l}\text { Mengungkap- } \\
\text { kan Perasaan }\end{array}$ & Tinggi & 100 & $\begin{array}{l}\text { Tinggi } \\
\text { Sedang } \\
\text { Rendah }\end{array}$ & $\begin{array}{l}33,3 \\
11,1 \\
55,6\end{array}$ \\
\hline $\begin{array}{l}\text { Menggunakan } \\
\text { cara-cara } \\
\text { efektif untuk } \\
\text { berperilaku } \\
\text { prososial }\end{array}$ & Tinggi & 100 & $\begin{array}{l}\text { Sedang } \\
\text { Rendah }\end{array}$ & $\begin{array}{l}33,3 \\
66,7\end{array}$ \\
\hline $\begin{array}{l}\text { Attribution of } \\
\text { others }\end{array}$ & Tinggi & 100 & $\begin{array}{l}\text { Tinggi } \\
\text { Rendah }\end{array}$ & $\begin{array}{l}22,2 \\
77,8\end{array}$ \\
\hline $\begin{array}{l}\text { Moral } \\
\text { Reasoning }\end{array}$ & Tinggi & 100 & $\begin{array}{l}\text { Tinggi } \\
\text { Rendah }\end{array}$ & $\begin{array}{l}33,3 \\
66,7\end{array}$ \\
\hline
\end{tabular}

Penemuan kedua dari penelitian ini adalah bahwa anak-anak usia 6 tahun yang tidak menunjukkan perilaku prososial menunjukkan kemampuan general intelligence yang tinggi. Dalam hal ini, mereka mampu untuk mengenal simbol pada ekspresi sederhana terutama untuk ekspresi wajah sedih, marah, takut, dan senang. Anak-anak juga mampu untuk menunjukkan persamaan dan perbedaan di antara ekspresi tersebut dan juga kemampuan kategorisasinya tinggi. Ketika diminta untuk menceritakan mengenai sebab akibat dari terjadinya ekspresi dalam dirinya pun, anak mampu menceritakan pengalaman yang dialaminya dengan baik. Namun, anak gagal untuk berempati terhadap kejadian yang dialami orang lain. Menurut Piaget, salah satu kesulitan yang berkembang pada anak usia 6 tahun ketika ia tidak mampu mencapai skema operatif adalah karena mereka cenderung melihat dari sudut pandangnya sendiri, karakteristik ini disebut egosentrisme. Kesulitan ini pada akhirnya mempengaruhi kemampuan empatinya.

Untuk anak-anak yang menunjuukkan perilaku prososial tidak ditemukan permasalahan pada kemampuan general intelligence. Anak mampu untuk menunjukkan perilaku prososial karena mereka mampu mengenali simbol, memahami perbedaan karakteristik sombol ekspresi wajah, kemudian mampu memahami kejadian-kejadian yang menunjukkan ekspresi wajah sedih, marah, senang, dan takut baik dari sudut pandang diri sendiri maupun dari sudut pandang orang lain sehingga kemampuan general intelligence-nya tinggi.

Untuk kemampuan perception of others, sampel anak yang tidak menunjukkan perilaku prososial terlihat menunjukkan grafik yang tinggi untuk kemampuan ini. Dalam hal ini, anak mampu untuk menginterpretasikan simbol-simbol ekspresi tersebut untuk mengkategorisasikan orang lain sebagai suatu tanda bahwa orang tersebut membutuhkan bantuan atau tidak dan mampu menginterpretasikan aturanaturan yang berlaku di lingkungan. Beberapa sampel juga menunjukkan kemampuan perception of others pada taraf sedang. Karakteristik pertama, bisa terlihat bahwa anak terlihat mampu untuk menginterpretasi simbol-simbol ekspresi wajah tersebut sebagai suatu tanda bahwa orang membutuhkan bantuan atau tidak namun tidak mampu memahami aturan yang ada di lingkungan. Dalam hal ini, anak mungkin tidak paham bahwa ia perlu membantu teman yang sedang menangis atau mengganggap lucu ketika teman sedang menangis. Ia juga menganggap hal tersebut boleh dilakukan karena ia kurang mampu membayangkan bagaimana perasaan orang lain ketika diperlakukan seperti itu sehingga ia tidak merasa bersalah ketika melakukan hal tersebut. Boyd dan Helen (2010) mengatakan bahwa orang dewasa atau agen sosialisasi sering menunjukkan kepekaan yang kurang dalam memberitahu anak untuk situasi-situasi seperti tidak mengucapkan terima kasih ataupun perilaku tidak menolong. Biasanya orang tua atau agen sosialisasi lebih perhatian dengan perilakuperilaku yang lebih besar seperti mencuri atau memukul sehingga terkadang anak juga jadi kurang memahami aturan-aturan yang berlaku di lingkungan untuk situasi-situasi prososial bahwa menolong itu perlu dan perlu mengucapkan terima kasih setelah dibantu. Byron (2009) juga mengatakan bahwa pola asuh juga bisa mempengaruhi kemampuan anak untuk memahami aturan dalam lingkungan. Untuk mengembangkan kemampuan anak dalam memahami aturan ini, perlu diberitahu mengenai pentingnya aturan ini tidak hanya kepada anak namun juga perlu untuk memberitahu kepada agen sosialisasi di sekitar anak untuk bisa membantu anak memahami aturan dan mampu memberikan reward berupa pujian ketika anak mampu mengikuti aturan sehingga perilaku tersebut tertanam di dalam diri anak.

Sebagian besar anak usia 6 tahun yang tidak menunjukkan perilaku prososial mengalami kesulitan 
dalam mengembangkan kemampuan role taking. Rata-rata anak yang memiliki kemampuan role taking juga memiliki kemampuan yang rendah pada kemampuan general intelligence dan perception of others. Kemampuan pemahaman emosi sederhana yang rendah bisa disebabkan karena anak tidak paham mengenai karakteristik ekspresi sederhana. Anak mengenali simbol namun tidak paham perbedaan dan kejadian yang menyebabkan orang merasakan perasaan seperti itu sehingga pada akhirnya ia gagal menginterpretasi kejadian prososial. Untuk itu anak perlu untuk ditingkatkan kemampuan empatinya dengan anak dihadapkan dengan kejadian-kejadian prososial terutama melalui role play sehingga anak bisa masuk ke dalam situasi yang dirasakan orang lain dan memberikan informasi mengenai alternatif cara untuk mengatasi kesedihan orang lain.

Disamping kemampuan role taking yang rendah, sebagian besar anak usia 6 tahun juga memiliki kemampuan attribution about others yang rendah karena terlihat anak tidak memahami hubungan sebab akibat dari suatu kejadian prososial sehingga pada akhirnya tidak memiliki motivasi berperilaku prososial. Menurut Eisenberg dan Mussen (1998) terdapat dua faktor yang mempengaruhi kemampuan seorang anak dalam memahami kemampuan attribution of others, yaitu faktor internal dan eksternal. Menurut data di lapangan melalui guru di sekolah, sebagian besar anak tidak berperilaku prososial dan menunjukkan kemampuan attribution of others yang rendah karena faktor internal. Anak kurang termotivasi untuk melakukan perilaku prososial bisa jadi dikarenakan bahwa anak kurang memahami runtutan kejadian dalam situasi prososial sehingga ia tidak mengetahui sebab akibat suatu kejadian. Anak kurang pahami ini bisa jadi karena anak kurang mengobservasi kejadian yang ada di lingkungan sehingga pada akhirnya dia tidak menyadari bahwa ada orang memerlukan perilaku prososial dari dirinya.

Dari data pemeriksaan terlihat bahwa anakanak yang tidak berperilaku prososial terlihat adanya kurang penanaman nilai-nilai moral reasoning. Hal ini bisa dikarenakan agen-agen sosialisasi kurang menggunakan prinsip reward dan punishment ketika anak menolong maupun tidak menolong. Agen sosialisasi juga kurang memperingatkan anak ketika ia tidak mau menolong. Menurut guru mereka tidak ingin memberikan reward ketika anak menolong karena akan mempengaruhi motivasi dari anak ketika ia menolong. Namun, mereka akan menegur dengan keras ketika ada anak tidak menolong, mengejek atau melakukan kekerasan kepada teman lain. Hal ini membuat nilai-nilai moral reasoning menjadi kurang meresap dalam diri anak dan menjadi suatu hal yang kurang penting.

\section{KESIMPULAN}

Berdasarkan hasil olah data dan analisa terhadap 11 orang anak usia 6 tahun yang menunjukkan perilaku prososial dan tidak prososial diperoleh kesimpulan sebagai berikut:

1. Pada anak usia 6 tahun yang mampu menunjukkan perilaku prososial tidak menunjukkan permasalahan dalam kemampuan sosiokognitif dan anak usia 6 tahun yang tidak menunjukkan perilaku prososial menunjukkan permasalahan dalam kemampuan sosiokognitif yang dimiliki.

2. Masalah-masalah yang terjadi pada anak usia 6 tahun yang memiliki kemampuan sosiokognitif rendah meliputi hal-hal sebagai berikut:

- Anak memiliki kemampuan general intelligence rendah terutama untuk dimensi kemampuan kategorisasi, kemampuan sebab akibat, dan kemampuan empati yang rendah.

- Anak memiliki kemampuan perception of others yang rendah terutama untuk dimensi kemampuan mengkategorisasikan orang dan aturan.

- Anak memiliki kemampuan role taking yang rendah terutama untuk dimensi kemampuan memahami emosi sederhana, kemampuan menceritakan perasaan orang lain, dan kemampuan menggunakan cara-cara yang efektif untuk mengurangi kesedihan orang lain yang rendah.

- Anak memiliki kemampuan attribution of others yang rendah terutama untuk pemahaman anak terhadap sebab akibat dari suatu kejadian sehingga menyebabkan anak kurang termotivasi untuk berperilaku prososial.

- Anak memiliki kemampuan moral reasoning yang rendah terutama untuk pemahaman anak mengenai nilai-nilai yang sudah diberikan oleh agen-agen sosialisasi seperti orang tua, guru, teman sebaya, maupun orang dewasa lain yang berinteraksi dengan anak.

- Anak yang memiliki kemampuan sosiokognitif yang rendah memiliki kebutuhan belajar seperti yang terurai berikut ini.

- Menfasilitasi anak supaya dapat meningkatkan kemampuan general intelligence-nya untuk bisa meningkatkan kemampuan pengetahuan dasar baginya sebelum bisa berperilaku prososial, yaitu dengan meningkatkan kemampuan kategorisasinya, sebab akibat, dan empatinya dengan mengembangkan skema berpikir figurative dan operatif pada diri anak.

- Meningkatkan kemampuan perception of others dalam diri anak untuk bisa menginterpretasi tanda-tanda atau simbol ekspresi menjadi suatu tanda bahwa seseorang membutuhkan bantuan dan membantu anak memahami aturan-aturan yang berlaku di lingkungan sehingga anak paham mana yang boleh dilakukan dan tidak boleh dilakukan ketika berhadapan dengan situasi-situasi prososial.

- Meningkatkan kemampuan role taking pada diri anak terutama kemampuan untuk memahami emosi-emosi sederhana, menceritakan perasaan 
yang dirasakan orang lain, dan kemudian memahami cara-cara efektif untuk mengurangi kesedihan orang lain sehingga anak mampu untuk memiliki pemahaman yang tepat ketika berhadapan dengan situasi-situasi prososial.

- Membantu anak meningkatkan kemampuan attribution of others dengan membantu anak untuk memahami runtutan kejadian agar bisa memahami sebab akibat dari suatu kejadian sehingga pada akhirnya anak termotivasi untuk menunjukkan perilaku prososial.

- Meningkatkan kepercayaan diri dalam diri anak untuk bisa berperilaku prososial dengan memberikan pemahaman kepada agen-agen sosialisasi di lingkungan sekitar anak, yaitu guru dan orang tua bisa untuk memberikan reward kepada anak agar mampu menunjukkan perilaku positif dan memberitahu anak ketika ia tidak melakukan perilaku prososial.

Untuk kebutuhan belajar dalam menfasilitasi anak untuk meningkatkan kemampuan sosiokognitif terutama dalam dimensi general intelligence, role taking, mempersepsi aturan, dan moral reasoning akan dilakukan dengan menggunakan metode pemberian seminar, role play, dan diskusi.

\section{DAFTAR PUSTAKA}

Bar-tal, D. (1976), Prosocial behavior: theory and research. Washington: Hemisphere Publishing Corporation.

Berk, L. E. (2008), Infants and children prenatal through middle childhood ( $6^{\text {th }}$ ed.). Boston: Allyn and Bacon

Bierhoff, H. W. (2002). Prosocial behavior. New York: Psychology Press.

Boyd, D. \& Helen, B. (2010), The growing child. Boston: Pearson International Edition.

Byron, T. (2009). Ensiklopedia perkembangan anak. Jakarta: Erlangga.

Eisenberg, N., (1983), The development of prosocial behavior. New York: Academic Press.

Eisenberg, N., (1983), The socialization and development of empathy and prosocial behavior. USA: Arizona State University.

Eisenberg, N. \& Paul, H. M. (1989). The roots of prosocial behavior in children. Cambridge: Cambridge University Press.

Eisenberg, N., Richard, A. F. \& Tracy, L. S. (2004), Prosocial development. USA: Youth Education Division of the Human Society.

Feldman, R. S. (1985), Social psychology theories research and application. New York: McGraw-Hill.

Hala, S. (1997), The development of social cognition. UK: Psychology Press Ltd.

Johnson, J. E., James, F. C. \& Thomas, D. Y. (1999). Play and early childhood development. USA: Addison Wesley Longman, Inc.

Joyce, B., Marsha, W. \& Emily, C. (2009), Models of teaching (Ed. 8). Yogyakarta: Pustaka Belajar.

McDevitt, Teresa, M. \& Omrod, Jeanne, E. (2002), Child development and education. New Jersey: Pearson Education, Inc.

Moeslichatoen, (2004), Metode pengajaran di taman kanakkanak. Jakarta: PT Rineka Cipta

Mutiah, D. (2010), Psikologi bermain anak usia dini. Jakarta: Kencana Prenada Media Group.
Papalia, D. E., Sally, W. O. \& Ruth, D. F. (2009), Human development $\left(10^{\text {th }}\right.$ ed.). Jakarta: Salemba Humanika.

Preusse, K. Tanpa Tahun. Fostering prosocial behavior in young children. Melalui www.earlychildhood.com

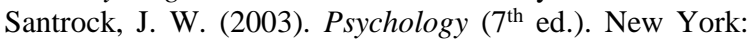
McGraw-Hill.

Santrock, J. W. (2007). Child development. New York: Mcgraw-Hill.

Sears, D. O., Jonathan, L. F., Anne, P. (1985). Psikologi sosial $\left(2^{\text {nd }}\right.$ ed.). Jakarta: Erlangga.

Staub, E. (1978). Positive social behavior and morality. New York: Academic Press.

Suminar, D. R. (2009), Membangun karakter anak melalui pretend play. Jurnal Psikologi Indonesia, VI (1), $1-11$. 